Article

\title{
Corrosion Study and Intermetallics Formation in Gold and Copper Wire Bonding in Microelectronics Packaging
}

\author{
Chwee Sim Goh ${ }^{1}$, , Wee Ling Eddy Chong ${ }^{1}$, Teck Kheng Lee ${ }^{1}$ and Christopher Breach ${ }^{2}$ \\ 1 Institute of Technical Education, 2 Ang Mo Kio Drive, 567720, Singapore; \\ E-Mails: eddy_w_1_chong@ite.edu.sg (W.L.E.C.); lee_teck_kheng@ite.edu.sg (T.K.L.) \\ 2 Promat Consultants, 160 Lentor Loop, \#08-05, Tower 6, 789094, Singapore; \\ E-Mail: cbreach@promat-consulting.com
}

* Author to whom correspondence should be addressed; E-Mail: goh_chwee_sim@ite.edu.sg; Tel.: +65-68797891; Fax: +65-65805020.

Received: 8 May 2013; in revised form: 31 May 2013 / Accepted: 2 July 2013 /

Published: 17 July 2013

\begin{abstract}
A comparison study on the reliability of gold $(\mathrm{Au})$ and copper $(\mathrm{Cu})$ wire bonding is conducted to determine their corrosion and oxidation behavior in different environmental conditions. The corrosion and oxidation behaviors of $\mathrm{Au}$ and $\mathrm{Cu}$ wire bonding are determined through soaking in sodium chloride $(\mathrm{NaCl})$ solution and high temperature storage (HTS) at $175{ }^{\circ} \mathrm{C}, 200{ }^{\circ} \mathrm{C}$ and $225{ }^{\circ} \mathrm{C}$. Galvanic corrosion is more intense in $\mathrm{Cu}$ wire bonding as compared to $\mathrm{Au}$ wire bonding in $\mathrm{NaCl}$ solution due to the minimal formation of intermetallics in the former. At all three HTS annealing temperatures, the rate of $\mathrm{Cu}-\mathrm{Al}$ intermetallic formation is found to be three to five times slower than $\mathrm{Au}-\mathrm{Al}$ intermetallics. The faster intermetallic growth rate and lower activation energy found in this work for both $\mathrm{Au} / \mathrm{Al}$ and $\mathrm{Cu} / \mathrm{Al}$ as compared to literature could be due to the thicker Al pad metallization which removed the rate-determining step in previous studies due to deficit in $\mathrm{Al}$ material.
\end{abstract}

Keywords: intermetallics; reliability; wire bonding; gold; copper 


\section{Introduction}

$\mathrm{Au}$ wire thermosonic bonding has been a mainstream semiconductor packaging process for many decades [1].The inert properties of Au make it an excellent choice for use when reliable manufacturing and applications in microelectronics packaging are required. The steep increase in Au prices has triggered the demand for high volume wire bonding process that can utilize $\mathrm{Cu}$ wire [2]. Barriers need to be overcome in $\mathrm{Cu}$ wire bonding due to the high oxidation rate and hardness of $\mathrm{Cu}$ wires. A number of studies have been conducted on $\mathrm{Cu}$ wire bonding [3-6] and the expected benefits of $\mathrm{Cu}$ wire over $\mathrm{Au}$ wire have been published [7-9]. The main benefits of using $\mathrm{Cu}$ wire bonding over Au wire bonding are lower material cost, higher electrical and thermal conductivity, and in long period HTS conditions, the lower reaction rates between $\mathrm{Cu}$ and $\mathrm{Al}$ serves to improve the long term reliability performance.

Although the many benefits of using $\mathrm{Cu}$ wire have been highlighted, and the $\mathrm{Cu}$ wire interconnect technology is already at the stage of mass manufacturing, cracking of the wire bond interface is often reported as a result of humidity or temperature effect [10,11]. Reports have also shown the poorer reliability of $\mathrm{Cu}$ as compared to $\mathrm{Au}$ in the presence of halides in conventional mold compounds and encapsulant materials [12]. The corrosion cell initiates due to the difference in electrochemical potential between $\mathrm{Al}$ and $\mathrm{Cu}$ in the presence of an electrolyte. The self-passivation of $\mathrm{Cu}$ worsens in an acidic environment where the $\mathrm{Cl}^{-}$ions in mold compounds act as a catalyst in the presence of moisture. This increases the corrosion rate of $\mathrm{Cu}$ by making the ranges of stable $\mathrm{pH}$ for $\mathrm{Cu}$ much narrower. Although the individual intermetallic phases that will corrode have been predicted in the previous study, microstructural evidence has not been reported to account for the corrosion behavior. The behavior of $\mathrm{Au}$ in halide environment has not been reported widely as the former has been esteemed as a noble metal. However, the potential difference between the Au wire and Al pad may pose an issue which can lead to severe galvanic corrosion in the Al pad, and subsequently to Au ball detachment.

The intermetallic growth mechanisms of $\mathrm{Cu}$ on $\mathrm{Al}$ pad metallization has been studied by a few researchers [2,3,6]. The activation energy reported varies from a wide range of $10.71 \mathrm{~kJ} / \mathrm{mol}$ to $60.9 \mathrm{~kJ} / \mathrm{mol}$. The thin Al metallization could be an important factor in affecting the rate of formation of $\mathrm{Cu}-\mathrm{Al}$ intermetallics due to the limiting material effect. The intermetallic growth mechanisms of $\mathrm{Au}$ on $\mathrm{Al}$ pad has been reported to a much lesser extent [3], and the activation energy of Au has not been widely published.

Accordingly, to address the shortfall in the corrosion studies conducted in halide environment, and the intermetallic growth mechanisms of $\mathrm{Au}$ and $\mathrm{Cu}$, this paper focuses on these two aspects in $\mathrm{Au} / \mathrm{Al}$ and $\mathrm{Cu} / \mathrm{Al}$ wire bonding. Comparison studies between $\mathrm{Au} / \mathrm{Al}$ and $\mathrm{Cu} / \mathrm{Al}$ will be carried out to examine the difference in their corrosion behaviors and intermetallics formation. 


\section{Experimental}

\subsection{Bonding Parameters and Material Properties of Au and $C u$ wires}

The $\mathrm{Au}$ and $\mathrm{Cu}$ wires were bonded to the $\mathrm{Al} / 0.5 \% \mathrm{Cu}$ pad of $1.2 \mu \mathrm{m}$ thickness using the ASM Eagle $60 \mathrm{AP}$ wire bonder. Tables 1 and 2 show the material properties of $\mathrm{Au}$ and $\mathrm{Cu}$ wires, and the bonding parameters used respectively. The number of bonded wires per sample is 100 .

Table 1. Material properties of $\mathrm{Au}$ and $\mathrm{Cu}$ wires.

\begin{tabular}{ccc}
\hline Property & $\mathbf{A u}$ & $\mathbf{C u}$ \\
\hline Composition & $99.99 \% \mathrm{Au}$ & $99.99 \% \mathrm{Cu}$ \\
Diameter $(\mu \mathrm{m})$ & 25 & 25 \\
Specified Breaking Load $(\mathrm{g})$ & $9.7 \sim 17.4$ & $6.8 \sim 14.5$ \\
Elongation $(\%)$ & $2 \sim 7$ & $6 \sim 18$ \\
\hline
\end{tabular}

Table 2. Wire bonding parameters.

\begin{tabular}{ccc}
\hline Parameter & Au & Cu \\
\hline Bonding Time (ms) & 10.0 & 9.0 \\
Bonding Force (gf) & 26.0 & 9.0 \\
Ultrasonic Power (mW) & 256 & 306 \\
\hline
\end{tabular}

\subsection{Corrosion Studies in Halide Environment}

For corrosion studies in $\mathrm{Cl}^{-}$environment, 10 dummy dies and 10 non-encapsulated dummy dies with $\mathrm{Au}$ and $\mathrm{Cu}$ wire bonds were soaked in random solutions of $0.1 \mathrm{M}, 0.01 \mathrm{M}$ and $0.001 \mathrm{M}$ of $\mathrm{NaCl}$ solutions. Through macroscopic analysis of the samples that have been soaked in the three solutions, it was observed that a significant number of bonded $\mathrm{Au}$ and $\mathrm{Cu}$ balls were detached from the bond pads. Comparison of the corrosion behaviors of $\mathrm{Au}$ and $\mathrm{Cu}$ ball bonds was not possible as most of the bonded balls were detached.

To give a more representative composition of $\mathrm{Cl}^{-}$in the actual operating environment, the content of $\mathrm{Cl}^{-}$in halogen-free mold compound was estimated. $500 \mathrm{ppm} \mathrm{Cl}^{-}$content was used as a guideline to compute the $\mathrm{NaCl}$ concentration for the test. An estimated concentration of $8.56 \times 10^{-3} \mathrm{M}$ of $\mathrm{NaCl}$ was computed for $500 \mathrm{ppm} \mathrm{Cl}^{-}$based on the diffusion coefficient of polymeric materials. Dummy dies andnon-encapsulated $\mathrm{Au}$ and $\mathrm{Cu}$ wire bonded dies were soaked at $25{ }^{\circ} \mathrm{C}$, and microscopic examination was conducted at $0,5,10,15,20,25$ and $30 \mathrm{~min}$ interval. The number of wires examined is 240 per time interval.

\subsection{Intermetallic Growth Rate Evaluation in Au/Al and Cu/Al Wire Bonding}

The $\mathrm{Au} / \mathrm{Al}$ and $\mathrm{Cu} / \mathrm{Al}$ wire bonding samples were placed in the air convection oven at $175^{\circ} \mathrm{C}, 200{ }^{\circ} \mathrm{C}$ and $225^{\circ} \mathrm{C}$ for $120,240,360$ and $480 \mathrm{~h}$ respectively. Table 3 shows the specific high temperature storage (HTS) conditions for intermetallic growth. 
Table 3. High temperature storage conditions for intermetallic growth.

\begin{tabular}{cccc}
\hline \multirow{2}{*}{ Condition } & \multicolumn{3}{c}{ Temperature $\left({ }^{\circ} \mathbf{C}\right)$} \\
\cline { 2 - 4 } & $\mathbf{1 7 5}$ & $\mathbf{2 0 0}$ & $\mathbf{2 2 5}$ \\
\hline \multirow{2}{*}{ Duration (h) } & 120 & 120 & 120 \\
& 240 & 240 & 240 \\
& 360 & 360 & 360 \\
& 480 & 480 & 480 \\
\hline
\end{tabular}

After completion of high temperature storage at each condition, the $\mathrm{Au} / \mathrm{Al}$ and $\mathrm{Cu} / \mathrm{Al}$ wire bonding samples were epoxy mounted, grinded and polished to $1 \mu \mathrm{m}$ finishing. Subsequently, the samples were ion polished using the JEOL IB-09010CP cross section polisher. The intermetallic thickness in Au/Al and $\mathrm{Cu} / \mathrm{Al}$ samples were then analyzed using the JEOL JSM-7600F field emission scanning electron microscope (FESEM) in the $\mathrm{LaBe}^{\mathrm{TM}}$. Low energy backscatter imaging mode to show a good contrast in the intermetallic layers and parent material. The intermetallic thickness is taken from an average of 10 measurements of three wire balls per sample.

\section{Results and Discussion}

\subsection{Corrosion Studies in Halide Environment}

In the presence of dissolved $\mathrm{CO}_{2}$ in the $8.56 \times 10^{-3} \mathrm{M}$ of $\mathrm{NaCl}$ in deionized water, the $\mathrm{pH}$ of the solution is about 5.0. According to Al Pourbaix diagram at $25{ }^{\circ} \mathrm{C}$ [13] as shown in Figure 1, a passivation layer is formed according to $\mathrm{Al}_{2} \mathrm{O}_{3}+3 \mathrm{H}_{2} \mathrm{O} \rightarrow 2 \mathrm{Al}(\mathrm{OH})_{3}$.

Figure 1. Pourbaix or potential-pH diagram of $\mathrm{Al}$ in aqueous environment, calculated for a temperature of $300 \mathrm{~K}$ and a molality of $1 \mathrm{e}^{-6} \mathrm{~mol} / \mathrm{kg}$ [13].

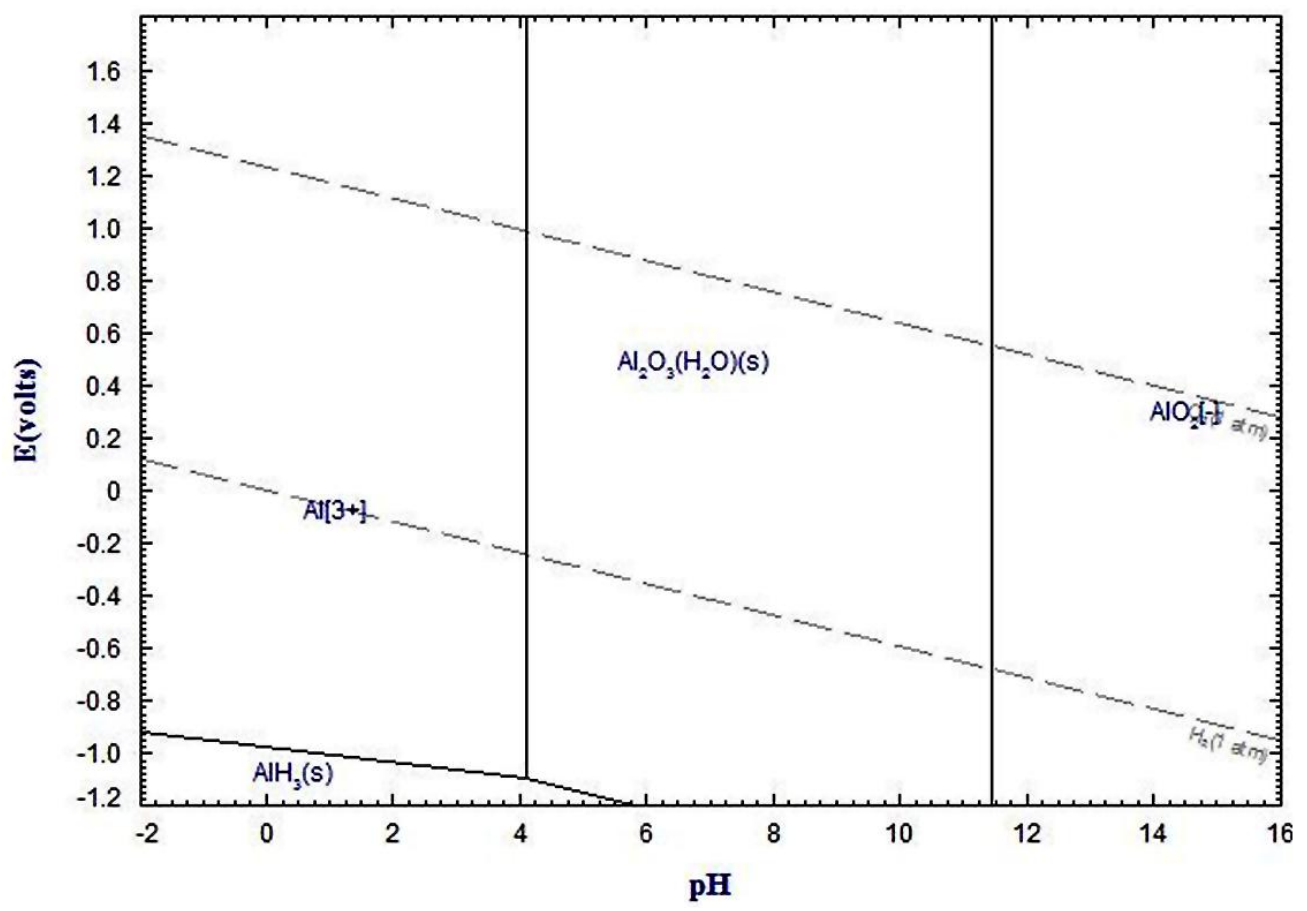


In the presence of $\mathrm{Cl}^{-}$in the slightly acidic deionized water, the following corrosion reactions are expected to take place on the Al bond pads [14]:

$$
\begin{gathered}
\mathrm{Al}(\mathrm{OH})_{3}+\mathrm{H}^{+}+\mathrm{Cl}^{-} \rightarrow \mathrm{Al}(\mathrm{OH})_{2} \mathrm{Cl}+\mathrm{H}_{2} \mathrm{O} \\
\mathrm{Al}(\mathrm{OH})_{2} \mathrm{Cl}+\mathrm{H}^{+} \rightarrow \mathrm{Al}(\mathrm{OH}) \mathrm{Cl}^{+}+\mathrm{H}_{2} \mathrm{O} \\
\mathrm{Al}(\mathrm{OH})_{2} \mathrm{Cl}+2 \mathrm{H}^{+} \rightarrow \mathrm{AlCl}^{2+}+2 \mathrm{H}_{2} \mathrm{O}
\end{gathered}
$$

Uniform pitting corrosion on the Al pads will take place in the slightly acidic halide environment according to Equations (1) to (3), and this is shown in the dummy dies without any wire bonding in Figure 2.

Figure 2. Uniform pitting corrosion on Al pads occurring on the dummy dies without any wire bonding.

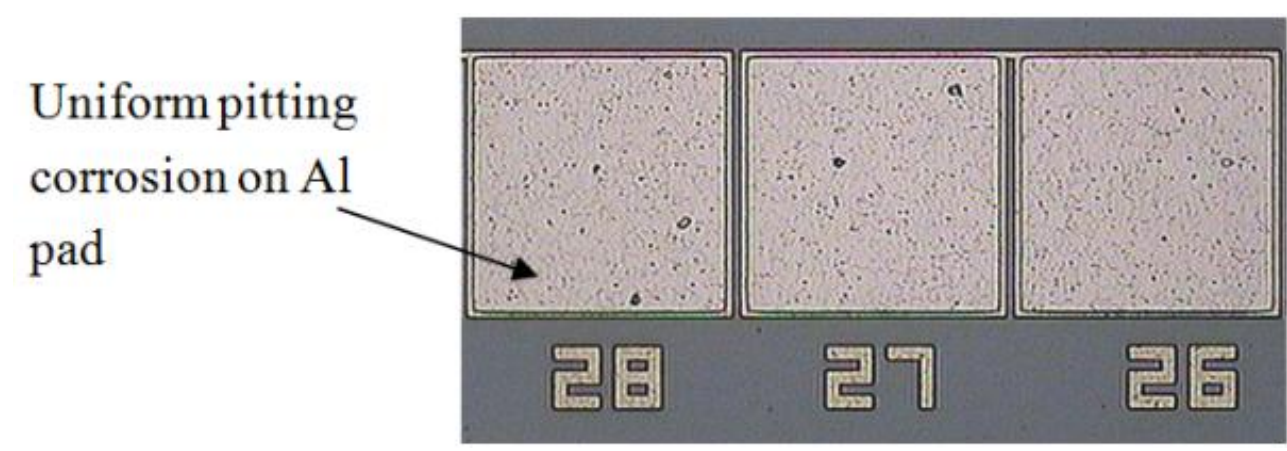

In addition to pitting corrosion on the $\mathrm{Al}$ pads, galvanic corrosion due to the presence of $\mathrm{Au}$ or $\mathrm{Cu}$ balls bonded on the pads can also take place. This is due to the electrode potential difference between $\mathrm{Au}$ or $\mathrm{Cu}$ and $\mathrm{Al}$. Figure 3 shows the mechanism of galvanic corrosion between the $\mathrm{Au}$ balls and $\mathrm{Al}$ pads. The Au balls in Figure 3a,b were still intact after 30 min of soaking in $\mathrm{NaCl}$ solution in the initiation and propagation stages, and were sheared off to reveal the state of corrosion beneath the balls. Figure $3 \mathrm{c}$ shows that corrosion has spread to the whole bonded area beneath the Au ball and the ball is detached without shearing.

Figure 3. Corrosion mechanism of $\mathrm{Au}$ balls and $\mathrm{Al}$ pad at the (a) initiation stage; (b) propagation stage and (c) detachment stage.

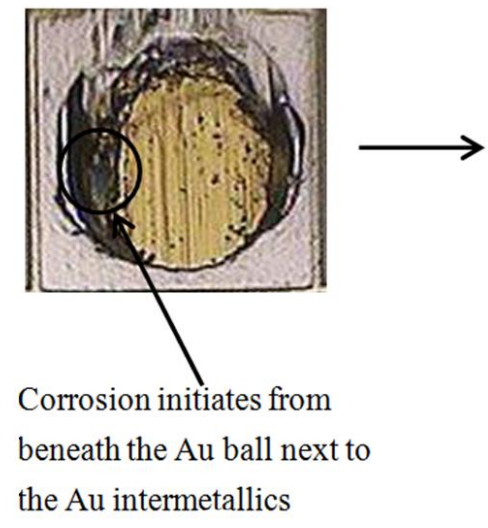

(a) Initiation

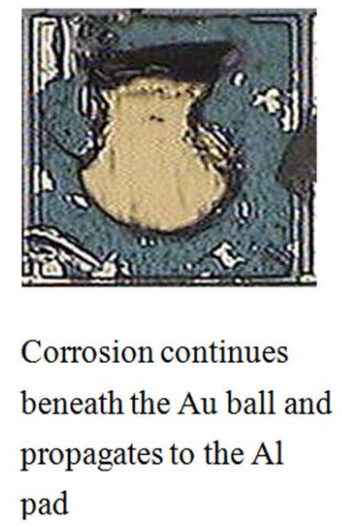

(b) Propagation

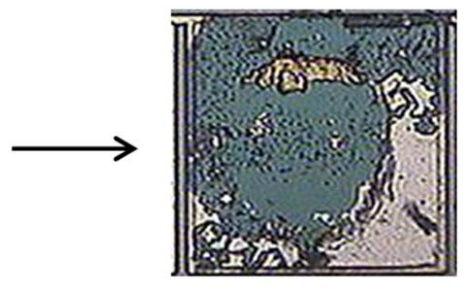

Corrosion ensues until the whole Au ball is detached from the $\mathrm{Al}$ pad without shearing

(c) Detachment 
Figure 4 shows the mechanism of galvanic corrosion between the $\mathrm{Cu}$ balls and $\mathrm{Al}$ pads, the mechanism of initiation is very similar to $\mathrm{Au}$ balls, except that $\mathrm{Cu}$ intermetallics were not present on the $\mathrm{Al}$ pad after the $\mathrm{Cu}$ ball was sheared off.

Figure 4. Corrosion mechanism of $\mathrm{Cu}$ balls and $\mathrm{Al}$ pads at (a) initiation and (b) propagation stage at 5 min soaking time.

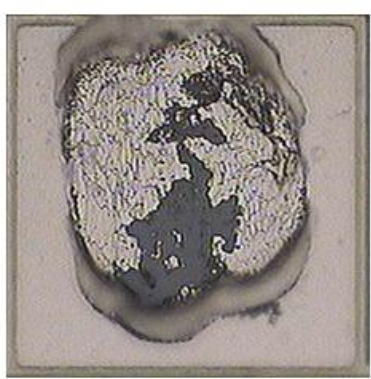

Corrosion initiates from beneath the $\mathrm{Cu}$ ball due to galvanic effect

(a) Initiation Stage

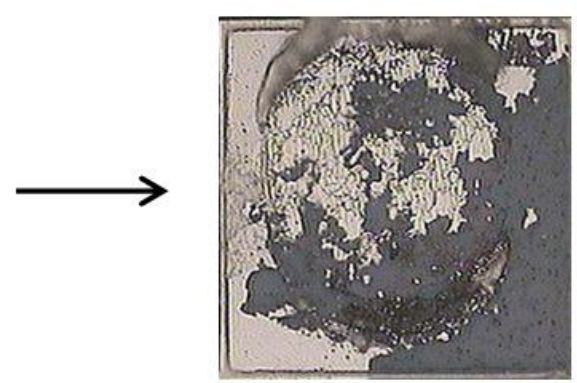

Corrosion propagates from beneath the $\mathrm{Cu}$ ball to the surrounding $\mathrm{Al}$ pad and resulted in detachment of the $\mathrm{Cu}$ ball

(b) Propagation Stage

Cross-sectional analysis of the $\mathrm{Cu}$ ball on $\mathrm{Al}$ pad further confirms that corrosion occurs primarily beneath the $\mathrm{Cu}$ balls and does not initiate from the $\mathrm{Al}$ pad (Figure 5).

Figure 5. Cross-sectional analysis of $\mathrm{Cu}$ ball on $\mathrm{Al}$ pad revealing corrosion initiation beneath the $\mathrm{Cu}$ ball.

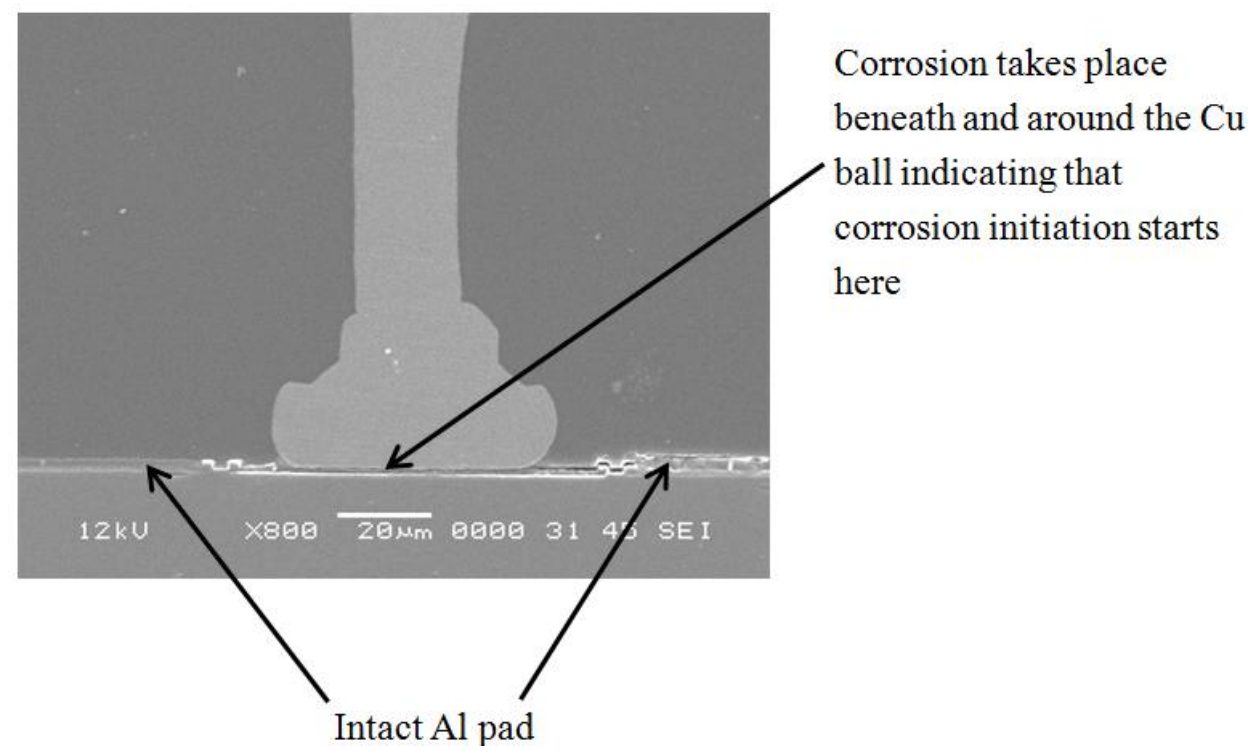

The results on the number of detached balls on $\mathrm{Au}$ and $\mathrm{Cu}$ wire bonding are shown in Figure 6a,b, respectively. It can be seen from Figure 6a that detachment of Au balls starts only after soaking in 
$\mathrm{NaCl}$ solution for $15 \mathrm{~min}$. The number of detached balls is also relatively constant, considering that the sample size used is 240 balls, and is kept below $10 \%$ even after $30 \mathrm{~min}$. For $\mathrm{Cu}$ wire bonding as shown in Figure 6 b, the percentage of detached balls increases steadily from 27.5 to 100 within 25 min.

Figure 6. Results on percentage of detached balls on (a) $\mathrm{Au}$ and (b) $\mathrm{Cu}$ wire bonding.

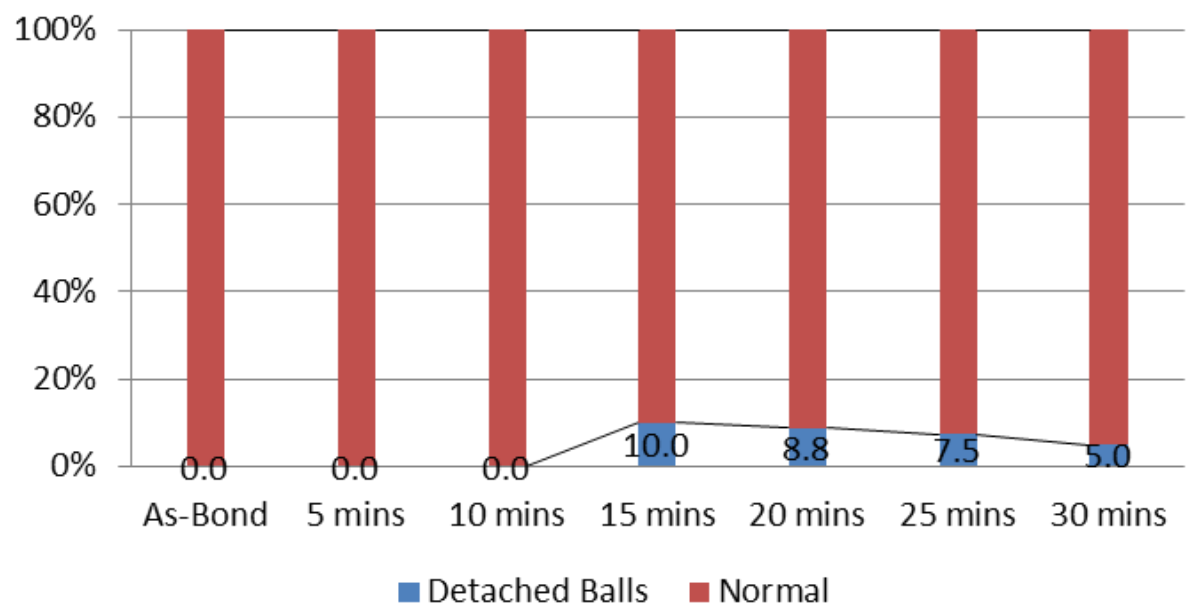

(a)

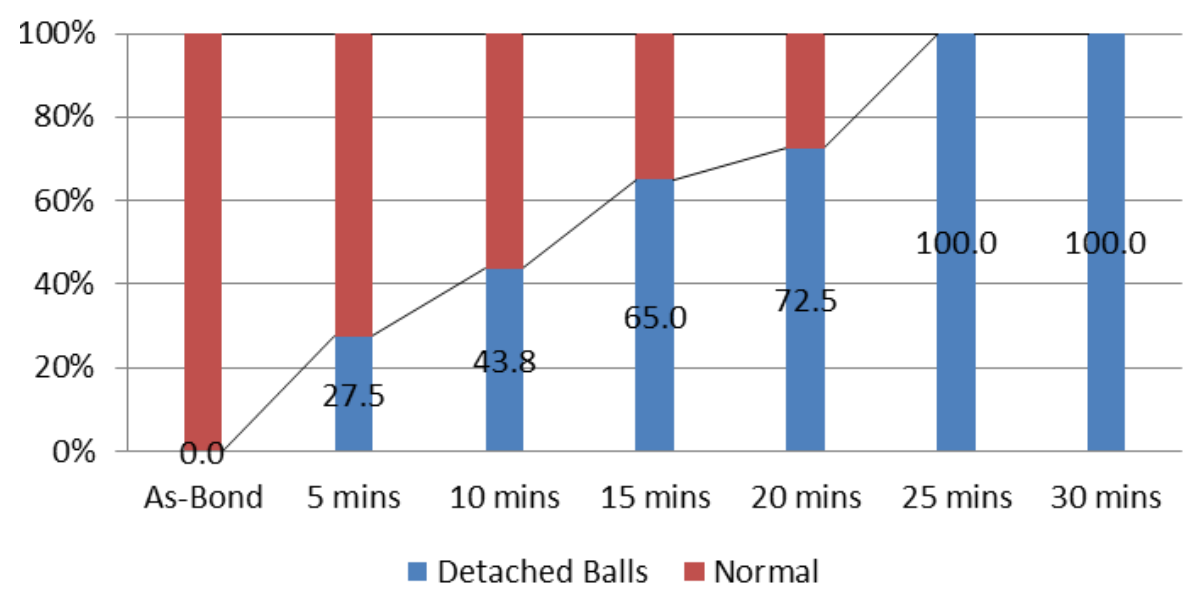

(b)

According to Figures 3-5, the extensive corrosion at the Al pads and the detachment of the bonded $\mathrm{Au}$ and $\mathrm{Cu}$ balls is due to galvanic corrosion between $\mathrm{Au} / \mathrm{Al}$ and $\mathrm{Cu} / \mathrm{Al}$. The standard potential difference between $\mathrm{Au}$ and $\mathrm{Al}$ is $3.2 \mathrm{~V}$, while that of $\mathrm{Cu}$ and $\mathrm{Al}$ is $2.0 \mathrm{~V}$. Theoretically, there should be more detached $\mathrm{Au}$ balls than $\mathrm{Cu}$ balls due to the more intense galvanic corrosion in $\mathrm{Au} / \mathrm{Al}$ wire bonding. However, it was found to be otherwise, as the corrosion of $\mathrm{Cu} / \mathrm{Al}$ is much more serious than $\mathrm{Au} / \mathrm{Al}$. $\mathrm{Au}$ is soft, and with the use of thermosonic bonding, good ball pad coverage is obtained due to the intermetallic formation beneath the Au balls. Therefore, $\mathrm{Cl}^{-}$solution cannot seep in easily to set up the corrosion cell and the corrosion rate is much lower. Figure 7a shows good ball pad coverage for $\mathrm{Au}$ after wire bonding. Intermetallic formation is very minimal in $\mathrm{Cu} / \mathrm{Al}$ at room temperature after wire bonding. Poor ball pad coverage and poor intermetallics are observed for $\mathrm{Cu}$ bonding in Figure $7 \mathrm{~b}$ which allows $\mathrm{Cl}^{-}$to seep beneath the pad to setup the corrosion cell. 
Figure 7. Optical micrographs showing (a) good ball pad coverage with Au intermetallics and (b) very minimal $\mathrm{Cu} / \mathrm{Al}$ intermetallics.

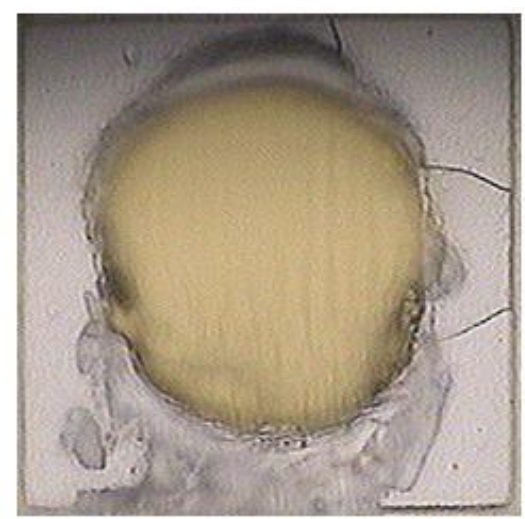

(a)

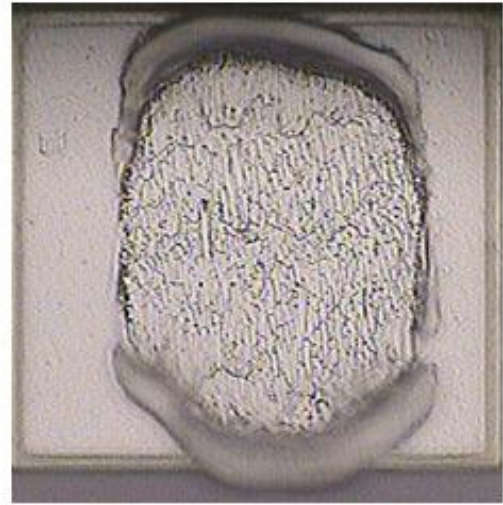

(b)

$\mathrm{Cu}$ in the presence of $\mathrm{Cl}^{-}$at $\mathrm{pH}$ less than 6 will form $\mathrm{CuCl}_{2}^{-}$according to the copper-chlorine Pourbaix diagram [15]. Formation of $\mathrm{CuCl}_{2}{ }^{-}$does not allow self-passivation of $\mathrm{Cu}$ to occur, and this will inevitably increase the rate of corrosion of $\mathrm{Cu}$. Furthermore, it is known that $\mathrm{Cl}^{-}$ions can act as a catalyst for $\mathrm{Cu}$ corrosion and weakens or dissolves the stable passivation oxide film. The likely intermetallic phases to be corroding in $\mathrm{Cu} / \mathrm{Al}$ wire bonding would be $\mathrm{CuAl}$ and $\mathrm{Cu}_{9} \mathrm{Al}_{4}$ due to the lower proportion of $\mathrm{Al}$ in the intermetallic [12]. In the case of $\mathrm{Au} / \mathrm{Al}$ wire bonding, $\mathrm{Au}_{4} \mathrm{Al}$ was shown to corrode in the presence of $\mathrm{Cl}^{-}[16,17]$.

\subsection{Intermetallic Growth Rate Evaluation in Au/Al and Cu/Al Wire Bonding}

Figure 8 shows a comparison of the intermetallics thickness of $\mathrm{Au} / \mathrm{Al}$ and $\mathrm{Cu} / \mathrm{Al}$ wire bonding at the mildest HTS conditions of $175{ }^{\circ} \mathrm{C}$ for $120 \mathrm{~h}$. It can be seen from Figure $8 \mathrm{a}, \mathrm{b}$ that under the same magnification of 10,000 times, the intermetallic layer in $\mathrm{Au} / \mathrm{Al}$ is about 5 times thicker than $\mathrm{Cu} / \mathrm{Al}$.

Figure 8. Intermetallic thickness of (a) $\mathrm{Au} / \mathrm{Al}$ and (b) $\mathrm{Cu} / \mathrm{Al}$ wire bonding at HTS conditions of $175^{\circ} \mathrm{C}$ for $120 \mathrm{~h}$.

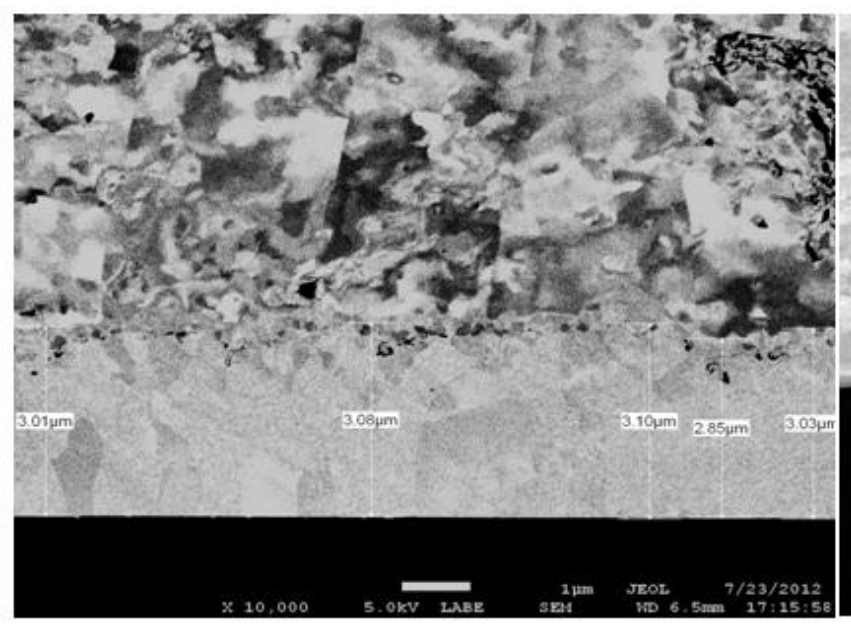

(a)

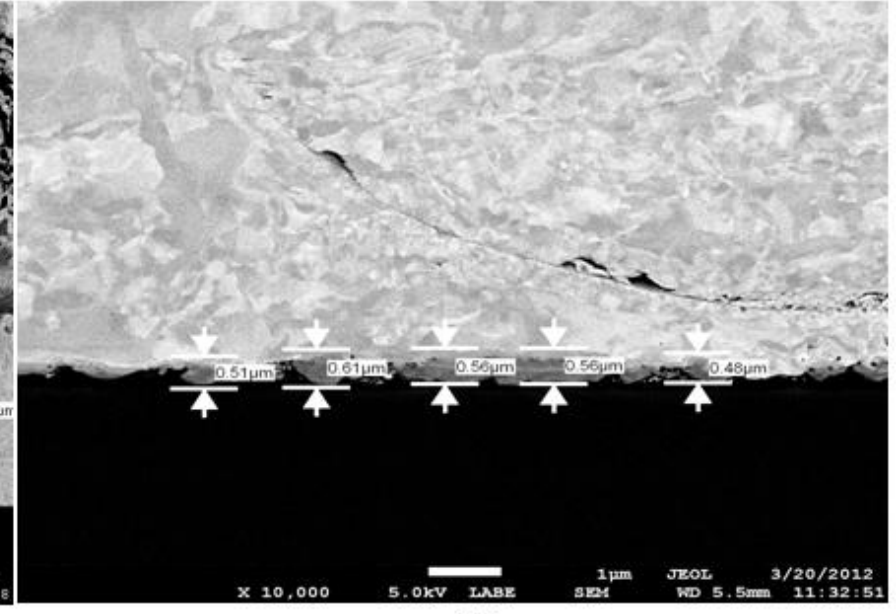

(b) 
The intermetallics measurement at different storage durations $(120 \mathrm{~h}, 240 \mathrm{~h}, 360 \mathrm{~h}$ and $480 \mathrm{~h})$ and temperatures $\left(175{ }^{\circ} \mathrm{C}, 200{ }^{\circ} \mathrm{C}\right.$ and $\left.225{ }^{\circ} \mathrm{C}\right)$ are shown in Figure 9. As shown in the figure, the intermetallic thickness of $\mathrm{Au}$ can range from 3 to 5 times higher than $\mathrm{Cu}$.

Figure 9. Intermetallics measurement at different HTS conditions.

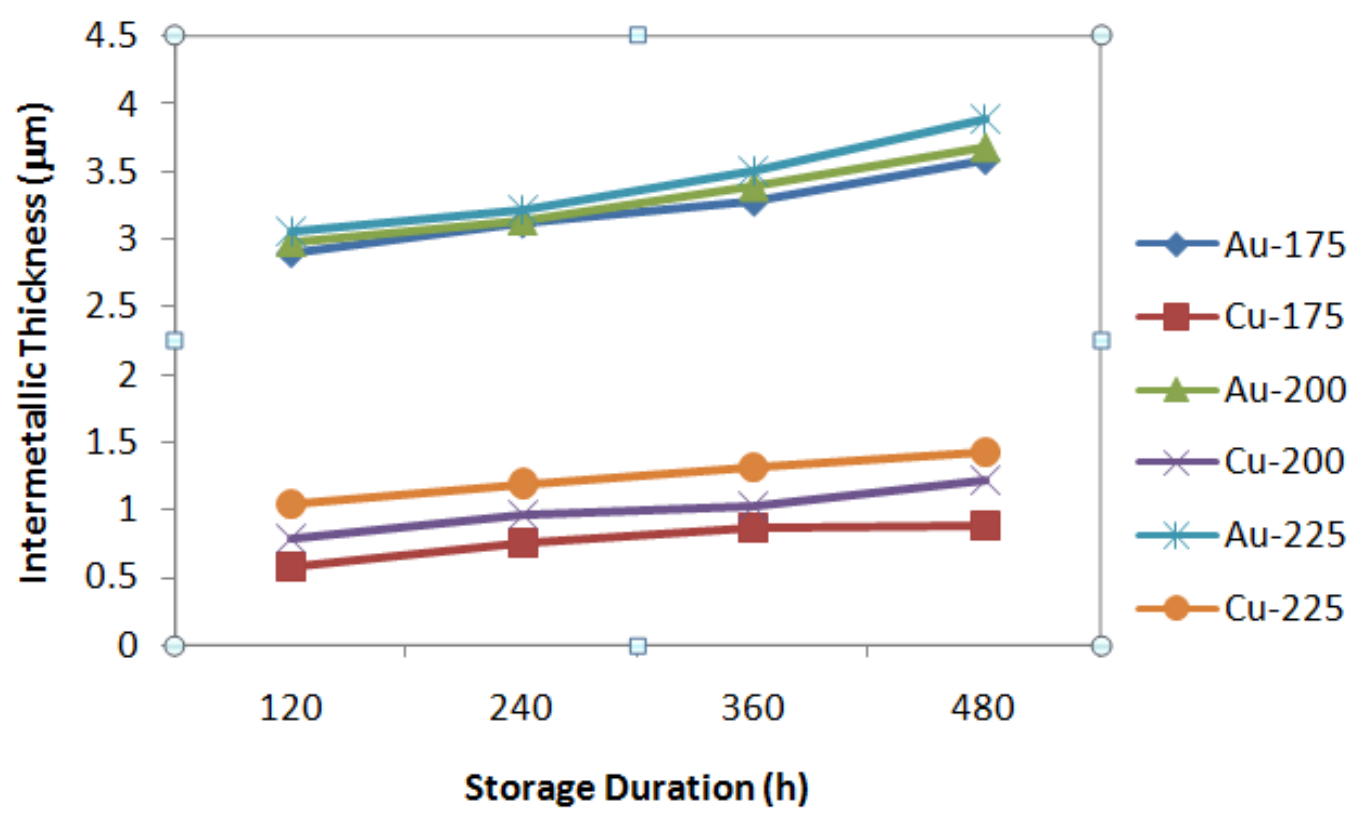

To calculate the intermetallic growth rate and the activation energy for intermetallic formation, the following two Equations [2] are used:

$$
X^{2}=K t+K_{1}
$$

where $X=$ IMC thickness $(\mu \mathrm{m})$

$t=$ Annealing time $(\mathrm{s})$

$K=$ Reaction rate of IMC formation $\left(\mu \mathrm{m}^{2} / \mathrm{s}\right)$

$K_{1}=$ Constant related to initial IMC thickness $\left(\mu \mathrm{m}^{2}\right)$

$$
K=K_{o} e^{(-\Delta Q / R T)}
$$

where $\Delta Q=$ Activation energy $(\mathrm{kcal} / \mathrm{mol})$

$R=\mathrm{Gas}$ constant $(1.99 \mathrm{cal} / \mathrm{mol} \mathrm{K})$

$T=$ Annealing Temperature $(\mathrm{K})$

$K_{o}=$ Pre-exponential Factor $\left(\mu \mathrm{m}^{2} / \mathrm{s}\right)$

Using Equation (4), three graphs of $\mathrm{X}^{2} v s . t$ is plotted to obtain the gradient $K$ at three different temperatures for $\mathrm{Au}$ and $\mathrm{Cu}$ wire bonding respectively as shown in Figure 10. $K_{1}$ is taken from the average of the three $y$-intercept values of the three graphs. 
Figure 10. Intermetallic growth rates $(\mathrm{K})$ at three different temperatures for (a) $\mathrm{Au}$ and (b) $\mathrm{Cu}$ wire bonding.

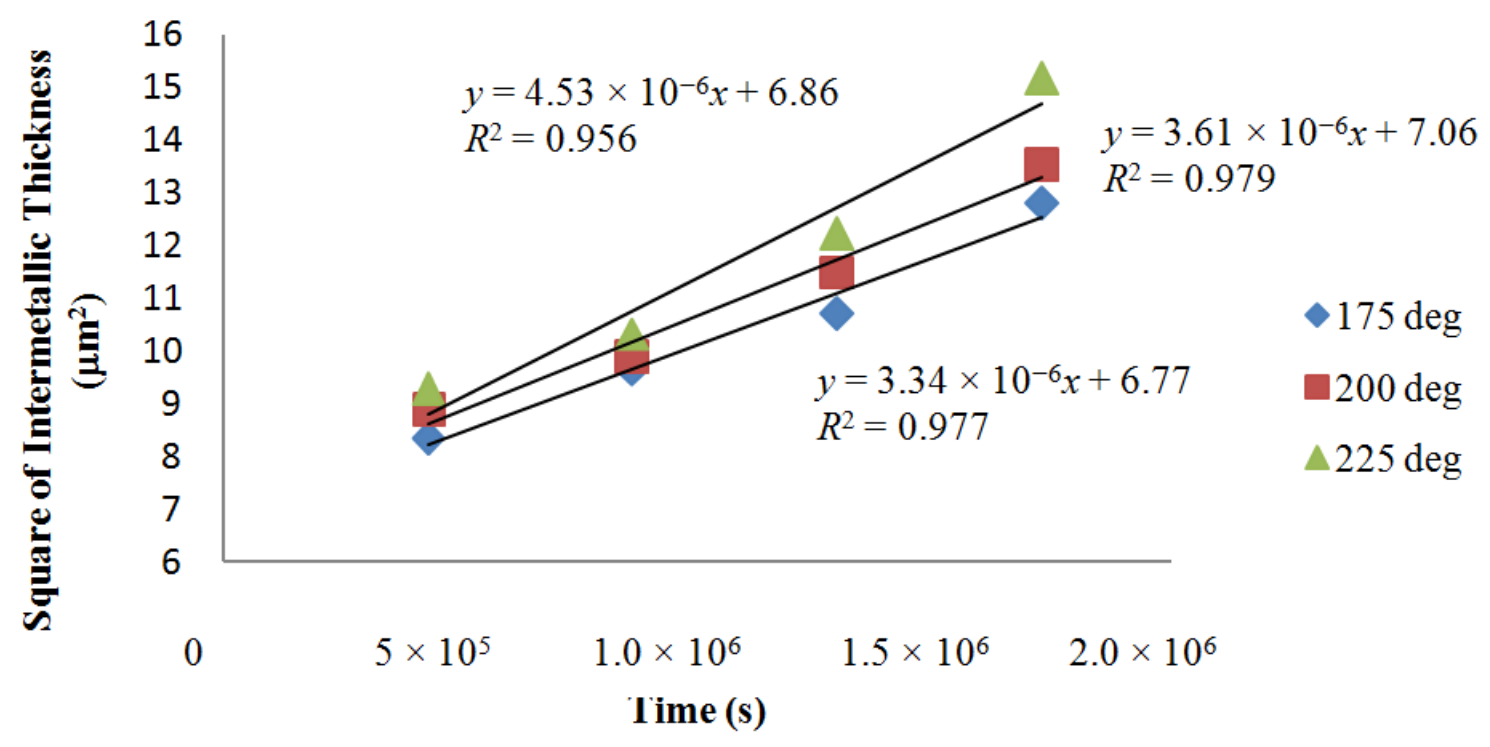

(a)

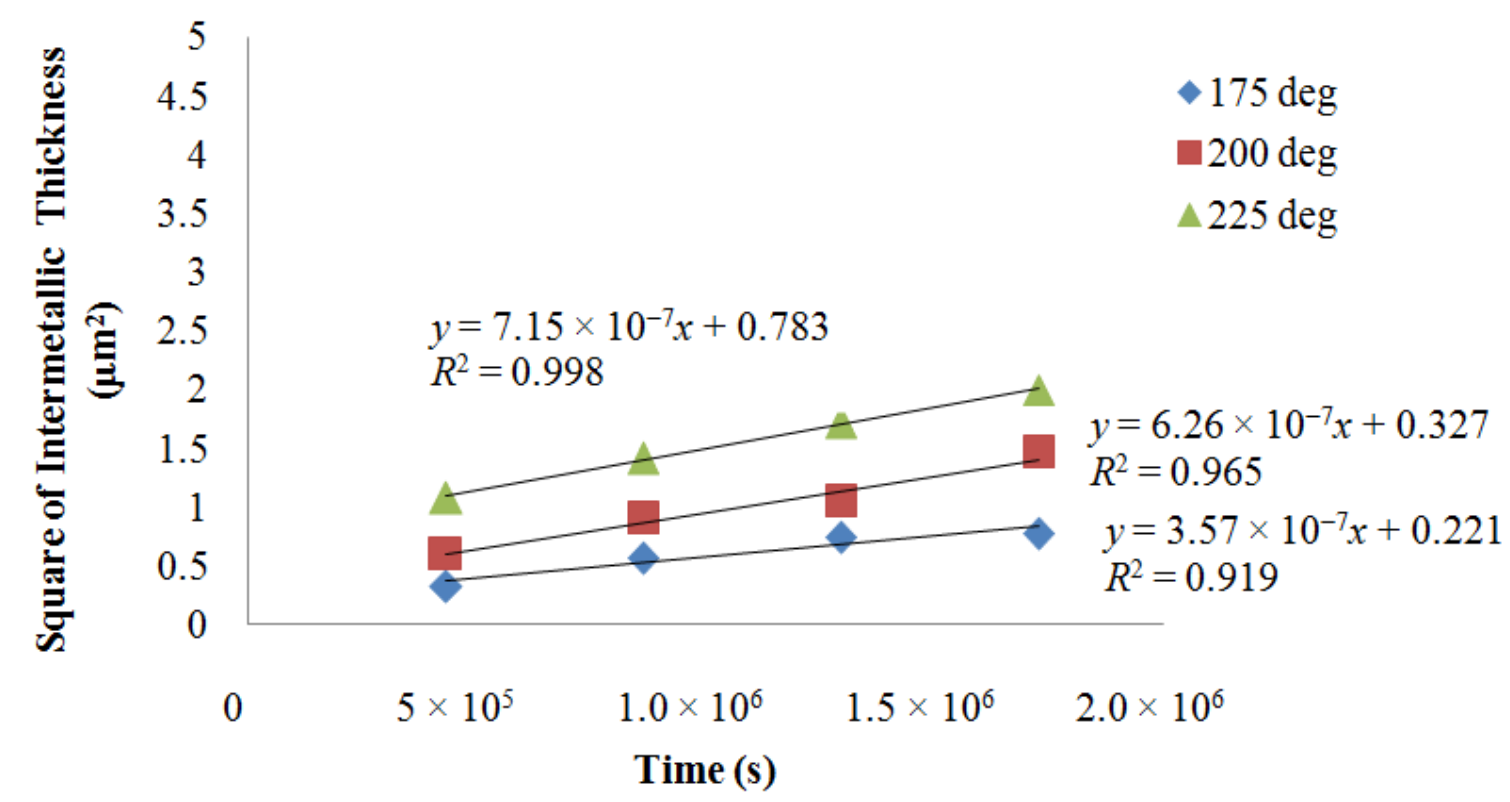

(b)

Using the $\mathrm{K}$ at three different temperatures, graphs of $\ln \mathrm{K} v s$. 1/T are plotted for $\mathrm{Au}$ and $\mathrm{Cu}$ respectively to obtain the activation energy $\Delta Q$ (Figure 11). The intermetallic growth rates and the activation energies obtained for both $\mathrm{Au}$ and $\mathrm{Cu}$ are compared with literature results as shown in Table 4. 
Figure 11. Graphs of $\operatorname{lnK} v s .1 / \mathrm{T}$ are plotted for $\mathrm{Au}$ and $\mathrm{Cu}$, respectively, to obtain the activation energy $\Delta Q$.

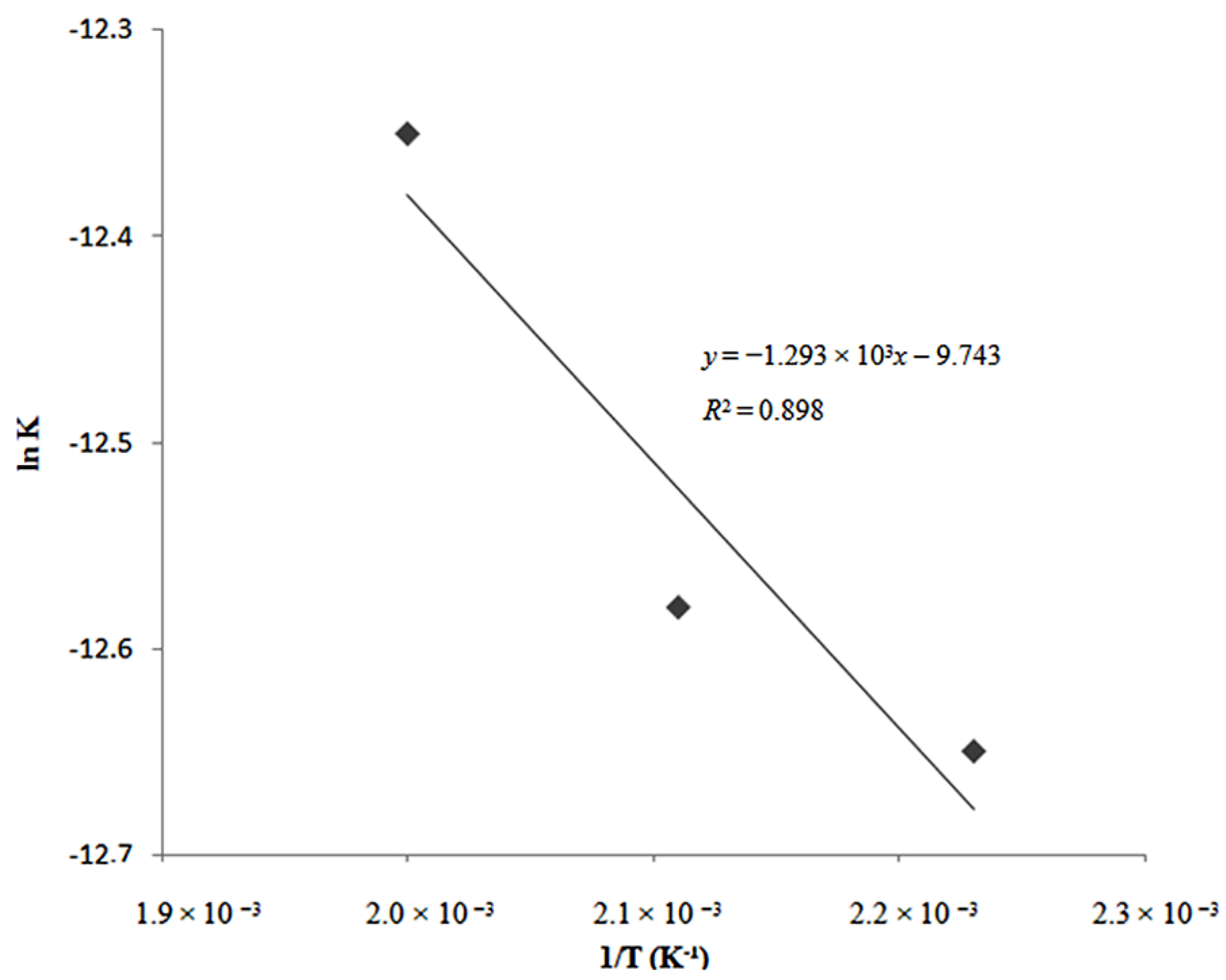

(a)

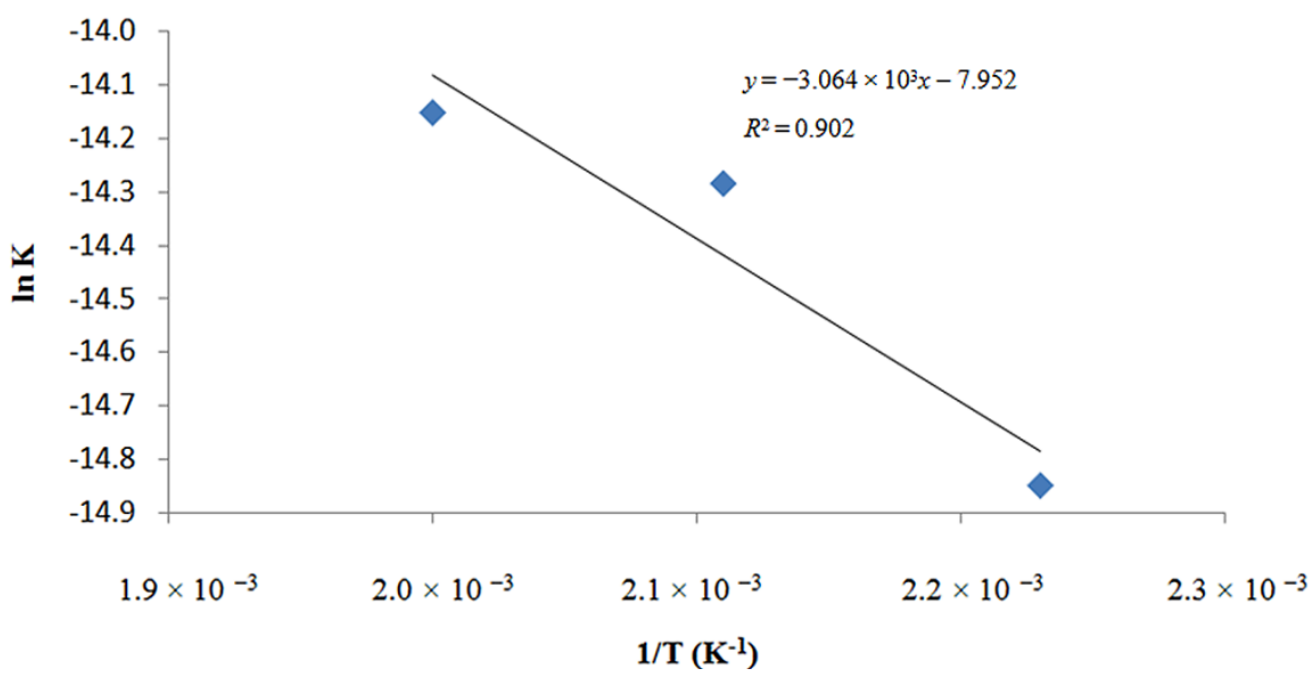

(b)

It can be seen from Table 4 that the rate of intermetallic formation and the activation energies of $\mathrm{Au} / \mathrm{Al}$ and $\mathrm{Cu} / \mathrm{Al}$ in the current study is faster and lower, respectively, than previous works. The $\mathrm{Al}$ pad metallization used in previous studies was $0.6 \mu \mathrm{m}$ thick, while the pad used in the current work is $1.2 \mu \mathrm{m}$ thick. The thin Al metallization in previous works could be the rate-determining step in preventing faster intermetallic formation and resulted in higher activation energy calculated since the thinnest intermetallic layer that is formed in $\mathrm{Cu} / \mathrm{Al}$ at the mildest HTS condition is already $0.58 \mu \mathrm{m}$. At more stringent HTS conditions, the intermetallic layers formed are even thicker. The reported and 
detectable intermetallic phases in $\mathrm{Cu} / \mathrm{Al}$ are mainly $\mathrm{CuAl}_{2}, \mathrm{CuAl}$ and $\mathrm{Cu}_{9} \mathrm{Al}_{4}$ [18,19]. Depending on the proportion of these three phases, the Al-rich intermetallics may have difficulties in forming due to a deficit of $\mathrm{Al}$, and resulted in a slower growth rate and higher activation energy. Similarly for $\mathrm{Au} / \mathrm{Al}$ wire bonding, Al-rich intermetallic phases such as $\mathrm{AuAl}_{2}$, may have difficulties in forming due to the smaller amount of $\mathrm{Al}$ available, especially when the $\mathrm{Au}$ intermetallics can grow above $3.8 \mu \mathrm{m}$ at stringent HTS conditions.

Table 4. Comparison of intermetallic growth rates and activation energies for $\mathrm{Au} / \mathrm{Al}$ and $\mathrm{Cu} / \mathrm{Al}$.

\begin{tabular}{|c|c|c|c|c|c|}
\hline Sample & Author & Time (h) & Temperature $\left({ }^{\circ} \mathbf{C}\right)$ & Rate $\left(\mu \mathrm{m}^{2} / \mathrm{s}\right)$ & $\Delta Q(\mathrm{kcal} / \mathrm{mol})$ \\
\hline \multirow{6}{*}{$\mathrm{Au}$} & \multirow{3}{*}{ Current } & $120,240,360,480$ & 175 & $3.34 \times 10^{-6}$ & \multirow{3}{*}{2.5} \\
\hline & & $120,240,360,480$ & 200 & $3.61 \times 10^{-6}$ & \\
\hline & & $120,240,360,480$ & 225 & $4.53 \times 10^{-6}$ & \\
\hline & \multirow{3}{*}{ [3] } & $2,25,75,100,300$ & 150 & $1.10 \times 10^{-14}$ & \multirow{3}{*}{-} \\
\hline & & $2,25,75,100,300$ & 280 & $2.40 \times 10^{-11}$ & \\
\hline & & $2,25,75,100,300$ & 350 & $3.90 \times 10^{-10}$ & \\
\hline \multirow{9}{*}{$\mathrm{Cu}$} & \multirow{3}{*}{ Current } & $120,240,360,480$ & 175 & $3.57 \times 10^{-7}$ & \multirow{3}{*}{6.1} \\
\hline & & $120,240,360,480$ & 200 & $6.26 \times 10^{-7}$ & \\
\hline & & $120,240,360,480$ & 225 & $7.15 \times 10^{-7}$ & \\
\hline & \multirow{3}{*}{ [3] } & $2,25,75,100,300$ & 150 & $1.88 \times 10^{-16}$ & \multirow{3}{*}{26} \\
\hline & & $2,25,75,100,300$ & 250 & $2.64 \times 10^{-13}$ & \\
\hline & & $2,25,75,100,300$ & 300 & $3.75 \times 10^{-12}$ & \\
\hline & \multirow{3}{*}{ [6] } & $100,250,500,1000$ & 150 & $2.15 \times 10^{-8}$ & \multirow{3}{*}{10.71} \\
\hline & & $100,250,500,1000$ & 200 & $2.56 \times 10^{-8}$ & \\
\hline & & $100,250,500,1000$ & 250 & $1.08 \times 10^{-7}$ & \\
\hline
\end{tabular}

The derived intermetallic growth rate equations for $\mathrm{Au} / \mathrm{Al}$ and $\mathrm{Cu} / \mathrm{Al}$ in this work are shown respectively in Equations (6) and (7):

$$
\begin{aligned}
& X^{2}=5.86 \times 10^{-5} e^{(-12935 / T)} t+6.9 \times 10^{-12} \\
& X^{2}=3.52 \times 10^{-4} e^{(-30645 / T)} t+4.4 \times 10^{-13}
\end{aligned}
$$

\section{Conclusions}

The following conclusions can be drawn from this study:

(1) Uniform pitting corrosion occurs on the Al pad in the absence of wire bonding.

(2) The good Au coverage and intermetallic formation beneath the Au balls strengthens the bonding between $\mathrm{Au}$ and $\mathrm{Al}$. Therefore, $\mathrm{Cl}^{-}$solution is not able to seep in easily to set up the corrosion cell, and the corrosion rate in $\mathrm{Au} / \mathrm{Al}$ is much lower than $\mathrm{Cu} / \mathrm{Al}$.

(3) The intermetallic thickness of $\mathrm{Au} / \mathrm{Al}$ can range from 3 to 5 times higher than $\mathrm{Cu} / \mathrm{Al}$.

(4) The thin $\mathrm{Al}$ metallization in previous works could be the rate-determining step in preventing faster intermetallic formation, and resulted in higher activation energy than what was observed in the current work. 


\section{Acknowledgments}

The authors would like to thank the World Gold Council for funding this work which is part of a project to understand the limitations of gold and copper ball bond reliability.

\section{Conflict of Interest}

The authors declare no conflict of interest.

\section{References}

1. Harmon, G. Wire Bonding in Microelectronics: Materials, Processes, Reliability and Yield, 2nd ed.; McGraw-Hill: New York, NY, USA, 1997.

2. England, L.; Jiang, T. Reliability of $\mathrm{Cu}$ Wire Bonding to Al Metallization. In Proceedings of IEEE Electronic Component Technology Conference, Reno, NV, USA, 29 May 2007; p. 1604.

3. Kim, H.J.; Lee, J.Y.; Paik, K.W.; Koh, K.W.; Won, J.H.; Choe, S.; Lee, J.; Moon, J.T.; Park, Y.J. Effects of $\mathrm{Cu} / \mathrm{Al}$ intermetallic compound (IMC) on copper wire and aluninum pad bondability. IEEE Trans. Compon. Packag. Technol. 2003, 26, 367-374.

4. Kurtz, J.; Cousens, D.; Dufour, M. Copper wire ball bonding. In Proceedings of the 34th Electron Component Conference, New Orleans, LA, USA, 14-16 May 1984; pp. 1-5.

5. Mori, S.; Yoshida, H.; Uchiyama, N. The development of new copper ball bonding wire. In Proceedings of the 38th Elentron Component Conference, Los Angeles, CA, USA, 9-11 May 1988; pp. 539-545.

6. Na, S.H.; Hwang, T.Y.; Park, J.S.; Kim, J.Y.; Yoo, H.Y.; Lee, C.H. Characterization of intermetallic compound (IMC) growth in $\mathrm{Cu}$ wire ball bonding on $\mathrm{Al}$ pad metallization. In Proceedings of the 61st Electronic Components and Technology Conference, Lake Buena Vista, FL, USA, 31 May-3 June 2011; pp. 1740-1745

7. Murali, S.; Srikanth, N.; Vath, C.J. Grains, deformation substructures and slip bands observed in thermosonic copper ball bonding. Mater. Charact. 2003, 50, 39-50.

8. Nguyen, L.T.; McDonald, D.; Danker, A.R.; Ng, P. Optimization of copper wire bonding on Al-Cu metallization. IEEE Trans. Compon. Packag. Manufact. Technol. Part A. 1995, 18, 423-429.

9. Tan, C.W.; Daud, A.R.; Yarmo, M.A. Corrosion study at the $\mathrm{Cu}-\mathrm{Al}$ interface in microelectronics packaging. Appl. Surf. Sci. 2002, 191, 67-73.

10. Hang, C.J.; Wang, C.Q.; Mayer, M.; Tian, Y.H.; Zhou, Y.; Wang, H.H. Growth behaviour of $\mathrm{Cu} / \mathrm{Al}$ intermetallic compounds and cracks in copper ball bonds during isothermal aging. Microelectron. Reliab. 2008, 48, 416-424.

11. Lee, C.C.; Higgins, L.M. Challenges of $\mathrm{Cu}$ wire bonding on low-k/Cu wafers with BOA structures. In Proceedings of the 60th Electronic Components and Technology Conference, Las Vega, NV, USA, 1-4 June 2010; pp. 342-349. 
12. Boettcher, T.; Rother, M.; Liedtke, S.; Ulrich, M.; Bollmann, M.; Pinkernelle, A.; Gruber, D.; Funke, H.-J.; Kaiser, M.; Lee, K.; et al. On the intermetallic corrosion of $\mathrm{Cu}$-Al wire bonds. In proceedings of the 12th Electronics Packaging Technology Conference, Singapore, 8-10 December 2010; pp. 585-590.

13. Facility for the Analysis of Chemical Thermodynamics. Available online: http://www.crct.polymtl.ca/factweb.php (accessed on 18 March 2013).

14. Foley, R.T.; Hguyen, I.H. The chemical nature of Al corrosion-V. Energy transfer in $\mathrm{Al}$ dissolution. J. Electrochem. Soc. 1982, 192, 464-467.

15. Beverskog, B.; Puigdomenech, I. SKI Rapport 98:19. Pourbaix diagrams for the system copper-chlorine at 5-100 ${ }^{\circ} \mathrm{C}$. Available online: http://www.stralsakerhetsmyndigheten.se/global/ publikationer/ski_import/010803/04318226039/98-19.pdf (accessed on 18 March 2013).

16. Lue, M.H.; Huang, C.T.; Huang, S.T.; Hsieh, K.C. Bromine and chlorine induced degradation of the $\mathrm{Au}-\mathrm{Al}$ bonds. J. Electron. Mater. 2004, 33, 1111-1117.

17. Schrapler, L.; Muller, T.; Knoll, H.; Petzold, M. Influence of intermetallic phases on bonding reliability in thermosonic $\mathrm{Au}-\mathrm{Al}$ wire bonding. In Proceedings of the 1st Electronic System Integration Technology Conference, Dresden, Germany, 5-7 September 2006; pp. 1266-1273.

18. Rajan, K.; Wallach, E.R. A transmission electron microscopy study of intermetallic formation in Al-Cu thin film couples. J. Cryst. Growth 1980, 49, 297-302.

19. Tamou, Y.; Li, J.; Russell, S.W.; Mayer, J.W. Thermal and ion beam induced thin film reactions in Cu-Al bilayers. Nucl. Instrum. Methods Phys. Res. B 1992, 64, 130-133.

(C) 2013 by the authors; licensee MDPI, Basel, Switzerland. This article is an open access article distributed under the terms and conditions of the Creative Commons Attribution license (http://creativecommons.org/licenses/by/3.0/). 